zeszyt 153, 2018, 7-24

doi: 10.4467/20833113PG.18.001.8476

Instytut Geografii i Gospodarki Przestrzennej UJ

Wydawnictwo Uniwersytetu Jagiellońskiego

\title{
ANTROPOGENICZNIE UWARUNKOWANE PRZEŁOMY SUMINY I WIERZBNIKA \\ JAKO PRZYKŁAD NATURALIZACJI SZTUCZNYCH KORYT RZECZNYCH (ZLEWNIA RUDY)
}

\author{
Maria Fajer
}

\section{Anthropogenically Determined Gorges of the Sumina and Wierzbnik Rivers as an Example of Naturalisation of Artificial River Channels (Ruda River Catchment)}

Abstract: The article describes anthropogenic transformations of relief features associated with former economic use of rivers and the changes that occurred in individual sections of artificial canals as a result of their naturalisation. The study was carried out in two river valleys - of the Sumina and Wierzbnik Rivers, which are located in the Ruda River catchment (within the Odra River drainage basin), on the boundary of the Rybnik Plateau and the Racibórz Basin. The use of water in these rivers for the purposes of former grain mills, sawmills and other industrial facilities as well as fish ponds involved the construction of bypasses. The deep erosion gullies recorded in the relief of the Sumina and Wierzbnik River valleys are in fact transformed anthropogenic forms: artificial river channels and old bypasses. In the Wierzbnik River valley, these canals - today dead, but still visible in relief, reflect the technical solutions which were once used to protect ponds from damage during floods. The sections of old artificial canals such as the man-made channel of the Sumina River, are still subject to naturalisation processes, being were later transformed by natural fluvial processes. This is reflected in an increase in channel sinuosity and the development of meanders. It is proposed that the erosive forms described in the article be referred to as anthropogenically determined river gorges.

Keywords: river erosion, bypasses, flood flow rates, anthropogenically transformed water systems 
Zarys treści: W artykule przedstawiono antropogeniczne przekształcenia rzeźby terenu, związane z dawnym, gospodarczym wykorzystaniem rzek, oraz zmiany, jakie zaszły na odcinkach sztucznych kanałów wodnych w efekcie ich naturalizacji. Badania przeprowadzono w dwóch dolinach rzecznych - Suminy i Wierzbnika - położonych w zlewni Rudy (dorzecze Odry), na pograniczu Płaskowyżu Rybnickiego i Kotliny Raciborskiej. Wykorzystanie wód tych rzek dla potrzeb pracujących tam dawniej młynów zbożowych, tartaków i innych obiektów przemysłowych, a także stawów rybnych, wiązało się z budową kanałów powodziowych (ulgi). Zapisane w rzeźbie dolin Suminy i Wierzbnika głębokie rozcięcia erozyjne są przekształconymi formami antropogenicznymi - korytami zastępczymi i dawnymi kanałami ulgi. W dolinie Wierzbnika kanały te - dziś martwe, lecz nadal czytelne w rzeźbie terenu - są świadectwem rozwiązań technicznych stosowanych w celu ochrony stawów przed zniszczeniem podczas wezbrań powodziowych. Odcinki dawnych sztucznych kanałów - koryt zastępczych Suminy przekształcane przez naturalne procesy fluwialne ulegają nadal naturalizacji. Odzwierciedleniem tego jest wzrost krętości koryta i rozwój meandrów. Zaproponowano, aby przedstawione w artykule formy erozyjne nazwać antropogenicznie uwarunkowanymi przełomami rzecznymi.

Stowa kluczowe: erozja rzeczna, kanały ulgi, przepływy powodziowe, antropogenicznie przekształcone systemy wodne

\section{Wprowadzenie}

Rzeźba terenu na Wyżynie Śląskiej i w jej bliskim sąsiedztwie należy do najbardziej przekształconych przez człowieka elementów środowiska. W południowej części regionu jej powszechne zmiany są związane $z$ intensywnym rozwojem w ostatnich 200 latach górnictwa węglowego, hutnictwa, osadnictwa i komunikacji. Lokalnie można jednak znaleźć także starsze dowody zaawansowanej aktywności gospodarczej. Występują one m.in. w dolinach rzecznych, od dawna zabudowywanych obiektami hydrotechnicznymi związanymi z działalnością zakładów wykorzystujących energię wodną i z hodowlą.

Na Śląsku stosowano w przeszłości różne metody zapobiegania skutkom powodzi. W XVI w. skutecznie przeciwdziałano powodziom poprzez budowę na masową skalę małych zbiorników śródpolnych oraz systemów dużych stawów lokalizowanych w dolinach rzecznych (Strumieński 1573; Nyrek 1997). W dnach dolin dopływów Rudy budowano stawy kaskadowe (tzw. stawy paciorkowe lub łańcuchowe). Lokalizowano stawy także na terasie nadzalewowej, m.in. w Paproci i Brantołce (Waga 2003). W latach 1794-1801 w dolinie Rudy było 20 dużych i kilkanaście mniejszych stawów, a w dolinie Suminy istniało około 80 stawów (Kocel 1995).

Większość stawów zachowanych do dziś w zlewni Rudy to dawne stawy klasztorne, które budowano od drugiej połowy XIII w. Właścicielem znacznej części tych terenów był wówczas zakon cystersów z Rud, umiejętnie gospodarujący zasobami wodnymi (Rybant 1977). Problemy związane z dużą nieregularnością przepływów 
w rzekach zakonnicy próbowali rozwiązać przez budowę obiektów i urządzeń hydrotechnicznych, m.in. kanałów powodziowych. Ich pozostałości, przemodelowane przez późniejsze procesy erozyjne, są współcześnie widoczne w krajobrazie den dolin Suminy i Wierzbnika.

$Z$ jednej strony wysoki stopień zawodnienia gruntu w dnie doliny Suminy i jej dopływów od dawna zachęcał człowieka do budowy stawów hodowlanych, z drugiej zaś wezbrania powodziowe stwarzały zagrożenie dla tych obiektów. W zlewni Rudy występowały one często i miały zwykle katastrofalne skutki. Powodzie zagrażały budowlom hydrotechnicznym zlokalizowanym na Suminie i Wierzbniku. Świadczą o tym badane odcinki pogłębionych i rozmytych kanałów wodnych. Wezbrania tych rzek są spowodowane, poza wysoką sumą opadów atmosferycznych, rodzajem utworów powierzchniowych w ich zlewniach. Znaczną powierzchnię zajmują w nich grunty słabo przepuszczalne, co w konsekwencji generuje duży spływ powierzchniowy. Ponadto w zlewni Wierzbnika w XIX w. na przyspieszenie spływu powierzchniowego wód miał wpływ sposób gospodarowania na terenach leśnych, m.in. trzebież lasów, melioracje na obszarach eksploatacji rud żelaza i wypasanie zwierząt w lasach (Waga 2003).

W wyniku funkcjonowania kanałów wodnych powstały przełomy rzeczne uwarunkowane antropogenicznie. Mają one, zgodnie z definicją przełomu (Migoń 2006), charakter wciosu lub jaru o wyraźnie bardziej stromych zboczach tworzących wysokie skarpy.

Celem badań jest przedstawienie antropogenicznych przekształceń rzeźby terenu związanych z dawnym gospodarczym wykorzystaniem rzek oraz zmian, jakie zaszły na odcinkach sztucznych kanałów wodnych Suminy i Wierzbnika w procesie ich naturalizacji.

\section{Obszar badań}

Zlewnie Suminy i Wierzbnika pokryte są w większości osadami czwartorzędowymi z okresu zlodowacenia odrzańskiego (fluwioglacjalne piaski ze żwirami i głazami, mułki i iły, a także gliny zwałowe i ich eluwia). Utwory akumulacji rzecznej, budujące wyższe terasy, pochodzą głównie z rozmytych serii fluwioglacjalnych. W dnach dolin tych rzek występują holoceńskie piaski, mady, namuły organiczne i torfy. Lokalnie, na powierzchni terenu odsłaniają się neogeńskie osady ilaste i piaszczyste (Kotlicka, Kotlicki 1979, 1980).

Umiarkowanie urozmaicona rzeźba terenu (ryc. 1A) w zlewniach tych rzek powstała podczas degradacji lądolodu odrzańskiego (Karaś-Brzozowska 1963; Lewandowski 2003). W okolicy Zwonowic, na obrzeżu zagłębienia końcowego jednej z faz zlodowacenia odrzańskiego, występują jednak ponad 40-metrowe deniwelacje. 
Tuż obok rzeka Sumina przełamała się przez barierę utworzoną z utworów morenowych i fluwioglacjalnych. Istotnym składnikiem rzeźby działów międzydolinnych są tam późnovistuliańskie wydmy i pola eolicznych piasków pokrywowych. Najwięcej wydm występuje nad Wierzbnikiem, koło Przerycia i Białego Dworu. Przybierają one tam kształty wałów podłużnych lub skośnych do kierunków wiatrów wydmotwórczych, a także wydm parabolicznych (Waga 1994). W ujściowych odcinkach dolin Suminy i Rudy występuje kilka teras rzecznych: I - niska, współczesna, zalewowa, II - holoceńska, do $2 \mathrm{~m}$ wysokości, III - z przełomu zlodowacenia wisły i początków holocenu (3-4 m wysokości) oraz IV - ze zlodowacenia wisły (5-8 m wysokości) (Waga 1994).

Efektem zróżnicowania przestrzennego utworów powierzchniowych w analizowanych zlewnich jest wykształcenie typów gleb o różnej wartości użytkowej. Gleby nieurodzajne porastał las, pełniący rolę wodochronną i retencyjną, natomiast gleby przydatne pod uprawy rolne (ryc. 1B) wykorzystywano już przed okresem zasiedlania tych ziem przez cystersów w XIII w. (Foltyn, Foltyn 2012). Na obszarze badań na uwagę zasługuje trwałość granicy rolno-leśnej podkreślonej szpalerami kilkusetletnich dębów. Z użytków rolnych wody odpływały szybko, niejednokrotnie gwałtownie wypełniając koryta rzek. Dna dolin często wykorzystywano na łąki i pastwiska lub zamieniano na stawy. W części stawów stosowano gospodarkę przemienną, przesuszano je i ugorowano albo wykorzystywano pod uprawy zbóż i warzyw lub jako łąki i pastwiska (Strumieński 1573; Nyrek 1995). Rozbudowany system stawów hodowlanych o różnej wielkości był w przeszłości jednym z czynników spowalniających spływ powierzchniowy wód w zlewniach Suminy i Wierzbnika (Nyrek 1995; Absalon 1998).

W zlewni Rudy średnie roczne sumy opadów w latach 1961-1990 wynosiły od 701 mm (Stanowice) do 816 mm (Królówka). Najwyższe średnie sumy opadów występują w lipcu (90-101 mm), a najniższe w lutym i marcu (31-46 mm) (Absalon 1998).

Na Suminie i Wierzbniku występują wezbrania wiosenne z maksimum w marcu. Najniższe przepływy są notowane we wrześniu (Absalon i in. 2003). Średnio co 2-3 lata obserwuje się także wezbrania letnie, związane z deszczami nawalnymi i rozlewnymi (Hibszer 1988). Średni przepływ wody w korycie Suminy (w przekroju wodowskazu w Nędzy) w latach 1972-1986 wynosił $0,65 \mathrm{~m}^{3} \cdot \mathrm{s}^{-1}$ (Hibszer 1988). W korycie Wierzbnika (u ujścia do Rudy) średni przepływ w $1995 \mathrm{r}$. wynosił 0,123 $\mathrm{m}^{3} \cdot \mathrm{s}^{-1}$, a maksymalny $0,286 \mathrm{~m}^{3} \cdot \mathrm{s}^{-1}$ (Absalon 1998). W czasie dużych powodzi (m.in. w latach: 1997, 2010 i 2016) maksymalne przepływy były wielokrotnie większe. Długotrwałe opady o dużej wysokości w lipcu 1997 r. wywołały jedną z największych powodzi w zlewniach Suminy i Wierzbnika. Zanotowane wtedy miesięczne sumy opadów w zlewni Suminy osiągnęły $414 \mathrm{~mm}$ (Zwonowice) (Absalon i in. 2003), a w zlewni Wierzbnika 317,7 mm (Stanica) (https://dane.imgw.pl/). Suma opadów z czterech dni (5-8 lipca) wyniosła 241,7-255,3 mm. Maksymalne sumy dobowe w zlewni Suminy 


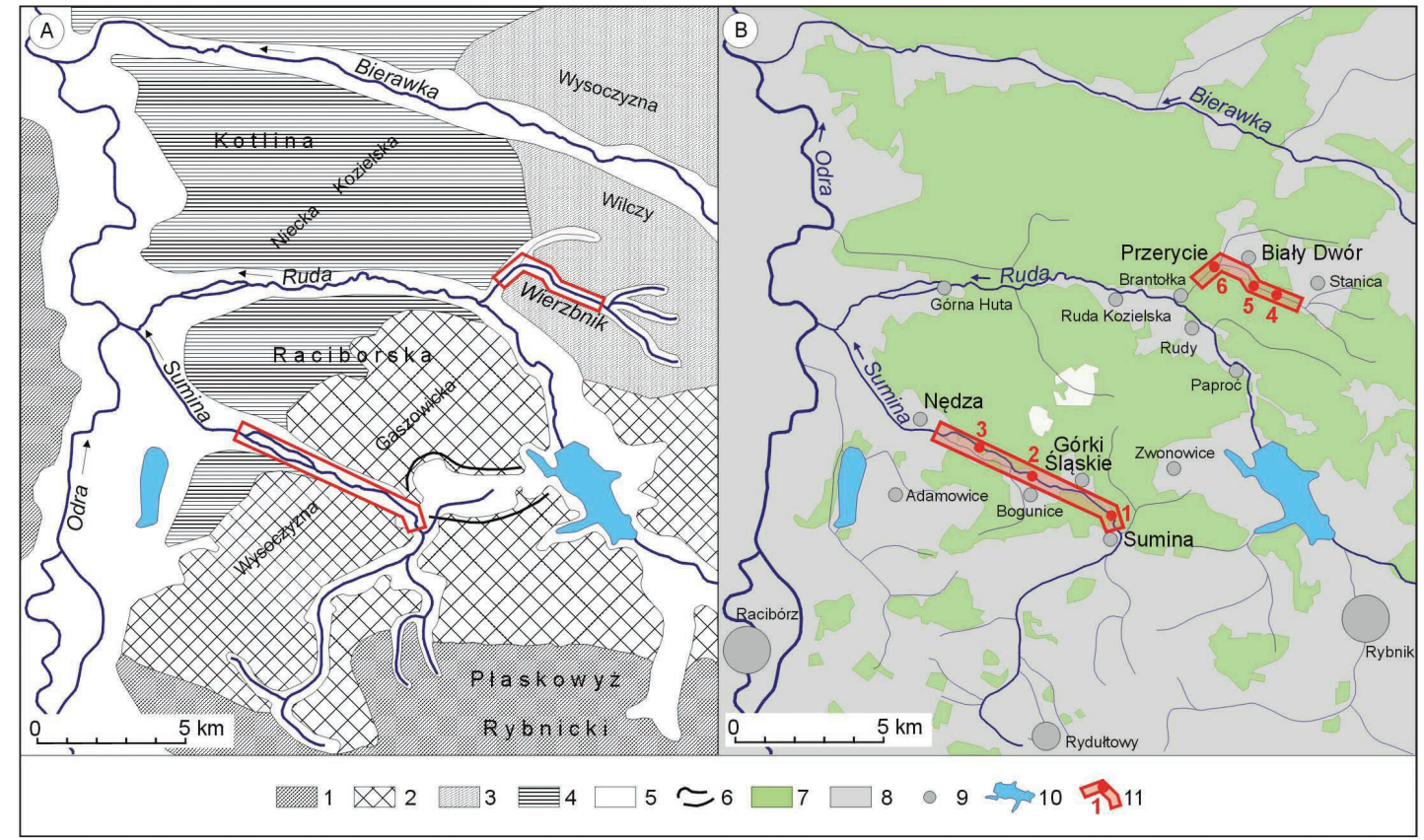

Ryc. 1. Analizowane odcinki rzek na tle: A - typów rzeźby i jednostek geomorfologicznych (granice jednostek geomorfologicznych wg Klimka 1972) oraz B - zgeneralizowanej mapy użytkowania terenu (opracowanie własne na podstawie mapy topograficznej w skali 1:100 000) Fig. 1. Analysed river sections against the background of: A - relief types and geomorphological units (boundaries of geomorphological units after Klimek 1972) and B - generalised land use map (own research based on a 1:100,000 topographic map)

Objaśnienia: 1 - płaskowyż lessowy, 2 - wysoczyzna pagórkowata, 3 - wysoczyzna płaska, gliniasta, 4 - równina piaszczysta, 5 - dna dolin, 6 - granica zagłębienia końcowego jednej z faz zlodowacenia odrzańskiego, 7 - lasy, 8 - użytki rolne, 9 - miejscowości wymienione w tekście, 10 - zbiorniki wodne, 11 - odcinki rzek objęte badaniami i stanowiska badawcze (1 - Sumina, 2 - Górki Śląskie, 3 - Mała Nędza, 4 - Paszki, 5 - Biały Dwór, 6 - Przerycie).

Explanations: 1 - loess plateau, 2 - hilly upland, 3 - flat loamy upland, 4 - sandy plain, 5 - valley bottoms, 6 - boundary of the depression left by glacier terminus during one of the Odra Glaciation phases, 7 - forests, 8 - farmland, 9 - towns/villages mentioned in the text, 10 - water bodies, 11 - river reaches covered by the study and study sites (1 - Sumina, 2 - Górki Śląskie, 3 - Mała Nędza, 4 - Paszki, 5 - Biały Dwór, 6 - Przerycie). 


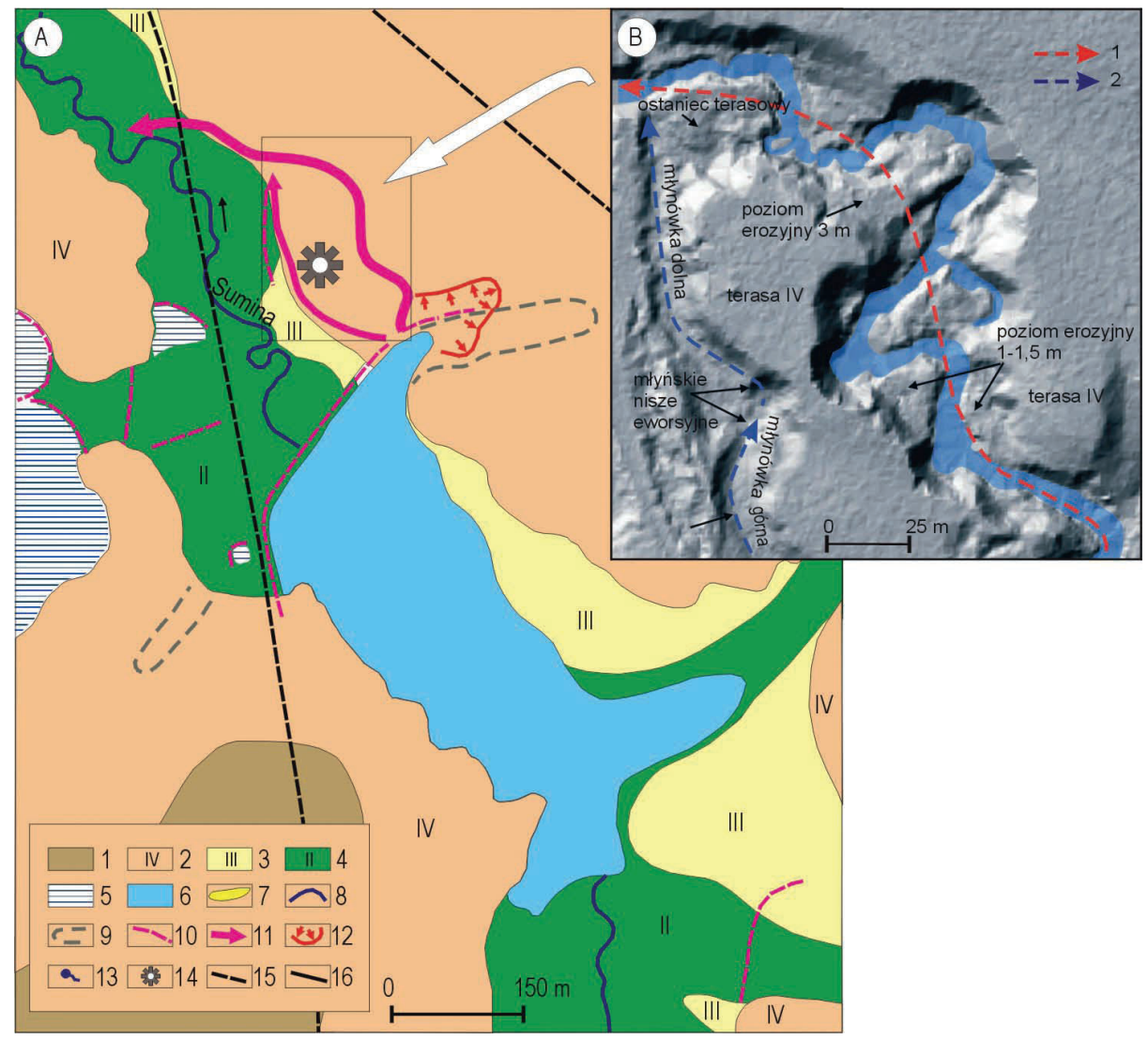

Ryc. 2. A - Rekonstrukcja zasięgu stawu (dla stanu wód podczas wezbrań powodziowych) i przebiegu kanałów w dolinie Suminy w Suminie, B - współczesne koryto Suminy poniżej dawnego stawu w Suminie

Fig. 2. A - Reconstruction of pond shoreline (for the water level reached during floods) and the course of canals in the Sumina River valley in Sumina, B - the contemporary channel of the Sumina River below the old pond in Sumina

Objaśnienia: A: 1 - wysoczyzna polodowcowa, 2 - terasa nadzalewowa wyższa (IV), 3 - terasa nadzalewowa niższa (III), 4 - terasa zalewowa (II), 5 - współczesny staw, 6 - zasięg dawnego stawu, 7 - wydma, 8 - koryto rzeki, 9 - niecka erozyjno-denudacyjna, 10 - grobla, 11 - odcinek przełomowy w śladzie przebiegu dawnego kanału wodnego, 12 - podcięcie erozyjne, 13 - nisza źródliskowa, 14 - lokalizacja tartaku, 15 - linia kolejowa, 16 - droga; B: 1 - pierwotny przebieg sztucznego koryta, 2 - kanał młynówki. Explanations: A: 1 - post-glacial upland, 2 - upper meadow terrace (IV), 3 - lower meadow terrace (III), 4 - floodplain (II), 5 - modern pond, 6 - old pond shoreline, 7 - dune, 8 - river channel, 9 - erosion-denudation basin, 10 - dyke, 11 - gorge reach along a former canal, 12 - erosion undercut, 13 - spring niche, 14 - sawmill location, 15 - railway line, 16 - road; B: 1 - the original course of the artificial canal; $2-$ mill race. 
wynosiły: 68,8 mm (Rydułtowy), 69,2 $\mathrm{mm}$ (Zwonowice) i 95,3 mm (Adamowice), a w zlewni Wierzbnika 63,0 mm (Stanica) (https://dane.imgw.pl/). Podczas tej powodzi przepływ Suminy wynosił $32 \mathrm{~m}^{3} \cdot \mathrm{s}^{-1}$ (Absalon 1998), był prawie 50 razy większy od przepływu średniego. Przepływ Wierzbnika oszacowano na $5 \mathrm{~m}^{3} \cdot \mathrm{s}^{-1}$, czyli ponad 40 razy przewyższał przepływy średnie (tab. 1).

\section{Metody}

W celu ustalenia lokalizacji dawnych stawów i zakładów wykorzystujących energię wód płynących Suminy i Wierzbnika wykorzystano mapy z lat 1736-1845 oraz mapy Messtischblatt i mapy Wojskowego Instytutu Geograficznego z lat 1870-1945 (tab. 2). Analizę treści tych map i porównanie ich ze stanem współczesnym wykonano metodą retrospektywną (Plit 2006). Jako podstawę opracowania przyjęto mapę topograficzną w skali 1:25 000 w układzie współrzędnych 1965, na której można precyzyjnie wskazać analizowane obiekty. Mapy niekartometryczne z XVIII w. i z I połowy XIX w. kalibrowano na podstawie punktów kontrolnych (skrzyżowania dróg, mosty). Ich treść dała informację o występowaniu i przybliżonej lokalizacji obiektów w rozpatrywanym czasie. Pozyskane informacje weryfikowano w terenie.

Rzeźbę wybranych obszarów przeanalizowano na ortofotomapie z 2015 r. (piksel $0,25 \mathrm{~m}$ ) zamieszczonej na stronie Geoportalu (http://geoportal.gov.pl/) i na wizualizacjach wygenerowanych z numerycznych modeli terenu, opartych na danych z lotniczego skaningu laserowego (LiDAR), które uzyskano z Centralnego Ośrodka Dokumentacji Geodezyjnej i Kartograficznej. Podczas badań terenowych wykonano szczegółowe kartowanie geomorfologiczne odcinków przełomowych na podkładzie mapy topograficznej w skali 1:10 000. Na podstawie analizy rzeźby na modelu oraz obserwacji terenowych wykonano rekonstrukcje zasięgu dawnych stawów, wyznaczając ich maksymalne powierzchnie odpowiadające stanom powodziowym.

W celu określenia warunków hydrologicznych i geomorfologicznych, w jakich dochodziło na badanym terenie do wzmożonych procesów erozyjnych, oszacowano przepływy podczas powodzi w lipcu 1997 r. (tab. 1) oraz obliczono spadki koryta i kanałów na odcinkach badawczych (tab. 3). Wartości dobowego oraz maksymalnego miesięcznego natężenia przepływu Suminy dla przekroju w Nędzy uzyskano z Instytutu Meteorologii i Gospodarki Wodnej - Państwowy Instytut Badawczy (https://dane.imgw.pl/). Maksymalny przepływ wody w Wierzbniku oszacowano dla przekroju trapezoidalnego usytuowanego pod mostem w Brantołce. Pomiary prędkości przepływu wykonano w nurcie, na odcinku o długości $20 \mathrm{~m}$, przy wykorzystaniu pływaka (Pociask-Karteczka 2006).

Aby ocenić ilość mas ziemnych przemieszczonych podczas budowy kanałów ulgi i koryt zastępczych, a także rozmiary późniejszej erozji, oszacowano początkowe 


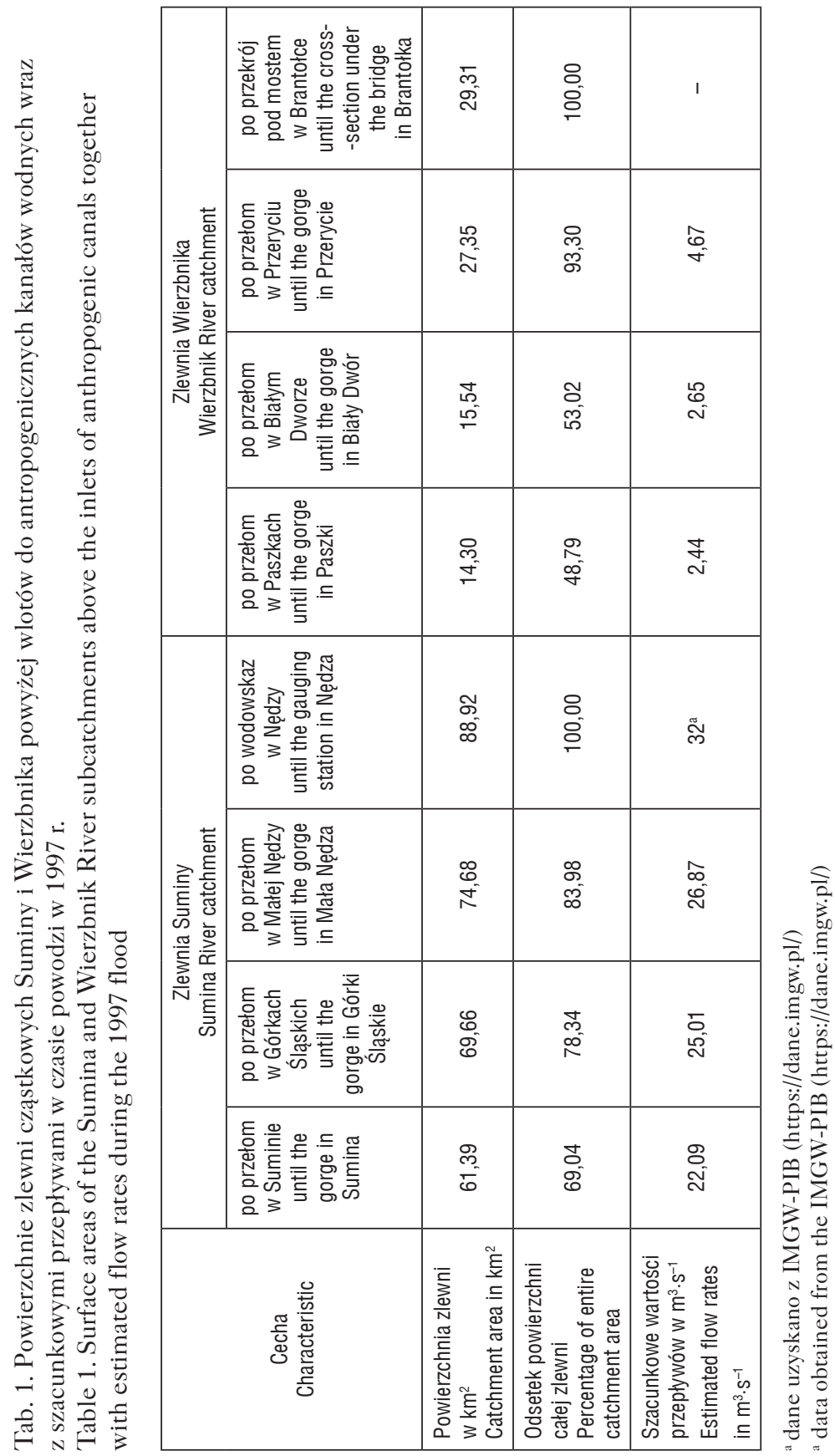


Tab. 2. Mapy archiwalne wykorzystane w badaniach

Table 2. Archival maps used in the study

\begin{tabular}{|l|c|l|}
\hline \multicolumn{1}{|c|}{$\begin{array}{c}\text { Tytuł mapy } \\
\text { Map title }\end{array}$} & $\begin{array}{c}\text { Rok wydania } \\
\text { Publication year }\end{array}$ & \multicolumn{1}{c|}{\begin{tabular}{c}
\multicolumn{1}{c|}{ Źrodło } \\
Source
\end{tabular}} \\
\hline $\begin{array}{l}\text { Principatus Silesiae Oppoliensis, } \\
\text { Johann Wieland, skala ca 1:220 000 }\end{array}$ & 1736 & $\begin{array}{l}\text { Repozytorium Cyfrowe Instytutów Naukowych } \\
\text { http://rcin.org.pl/dlibra }\end{array}$ \\
\hline $\begin{array}{l}\text { Topographisch-militärischer Atlas von Schlesien, } \\
\text { skala ca 1:200 000 }\end{array}$ & 1809 & $\begin{array}{l}\text { Biblioteka Cyfrowa Uniwersytetu Wrocławskiego } \\
\text { http://www.bibliotekacyfrowa.pl/dlibra }\end{array}$ \\
\hline Preußisches Urmesstischblatt, skala 1:25 000 & 1827 & $\begin{array}{l}\text { Prywatne zbiory Henryka Postawki } \\
\text { www.barglowka.pl }\end{array}$ \\
\hline $\begin{array}{l}\text { Topographische Special-Karte von Central } \\
\text { Europa (Reymann's Specialkarte), } \\
\text { skala ca 1:200 000 }\end{array}$ & 1845 & $\begin{array}{l}\text { Repozytorium Cyfrowe Instytutów Naukowych } \\
\text { http://rcin.org.pl/dlibra }\end{array}$ \\
\hline $\begin{array}{l}\text { Topographische Karte (Messtischblatt), } \\
\text { skala 1:25 000 }\end{array}$ & $1870-1945$ & $\begin{array}{l}\text { Mapster } \\
\text { http://igrek.amzp.pl }\end{array}$ \\
\hline $\begin{array}{l}\text { Mapy topograficzne Wojskowego Instytutu } \\
\text { Geograficznego, skala 1:25 000 }\end{array}$ & $\begin{array}{l}\text { Archiwum Map Wojskowego Instytutu } \\
\text { Geograficznego 1919-1939 } \\
\text { http://polski.mapywig.org }\end{array}$ \\
\hline
\end{tabular}

objętości kanałów oraz objętości współczesnych dolin w odcinkach przełomowych. Kubaturę przełomów oszacowano metodą sumowania objętości brył elementarnych (Paleczek 2015). Odcinki przełomów podzielono na kilkadziesiąt segmentów, które można było porównać do brył geometrycznych. Dla ułatwienia obliczeń wydzielano przede wszystkim graniastosłupy o podstawie trójkąta lub trapezu, rzadziej prostopadłościany. Ustalono ich charakterystyczne wymiary, korzystając z numerycznego modelu terenu i pomiarów wykonanych w terenie przy użyciu dalmierza laserowego. Następnie obliczono objętości i zsumowano je dla poszczególnych odcinków przełomów.

\section{Wyniki}

W morfologii dna doliny Suminy występują trzy głębokie rozcięcia erozyjne o charakterze przełomów: w Suminie, Górkach Śląskich i w Małej Nędzy (ryc. 1), którymi przebiega jej koryto. Podobna sytuacja istnieje w dolinie Wierzbnika, gdzie formy takie powstały w Paszkach, Białym Dworze i Przeryciu. Wierzbnik nadal płynie jednak osią doliny, a trzy wspomniane rozcięcia są usytuowane poza dnem doliny. Szczegółowa analiza pozwoliła stwierdzić, że mają one założenie antropogeniczne. Pierwotnie były to kanały przerzutowe, odprowadzające nadmiar wód rzecznych poza kompleksy stawów i młyny wodne, co było szczególnie ważne w czasie wysokich wezbrań. Wszystkie wymienione formy rozcinają fragmenty wyższych teras na odcinkach: od $380 \mathrm{~m}$ do 3,48 km w przypadku Suminy i od $370 \mathrm{~m}$ do $669 \mathrm{~m}$ 


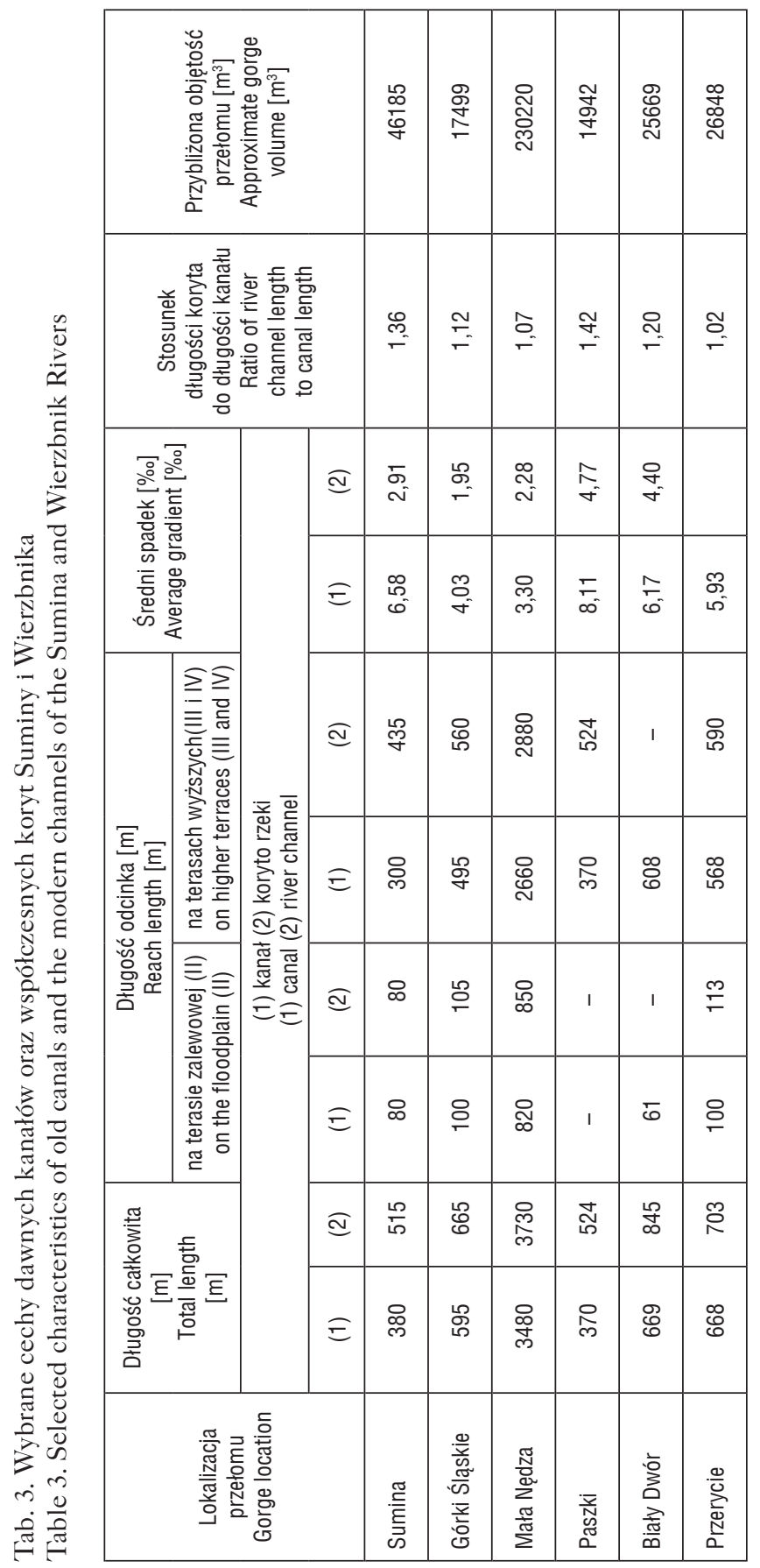


w dolinie Wierzbnika (tab. 3), przy czym kanał w Małej Nędzy przebiegał zarówno przez terasę wyższą, jak i niższą. W ich obrębie współczesna rzeka meandruje, stąd różnice w długości koryt i kanałów. W dolinie Wierzbnika trzy badane kanały ulgi poprowadzono na terasie IV. Dziś formy o charakterze przełomów antropogenicznych w Paszkach, Białym Dworze i Przeryciu są martwe.

Z analizy dawnych map wynika, że w okresie 1736-1920 wzdłuż całej Suminy zlokalizowane były 22 młyny wodne. Na badanym odcinku rzeki w 1736 r. istniało 12 stawów młyńskich i rybnych. Woda Wierzbnika, przepływającego przez obszary rudonośne, była źródłem energii mechanicznej niezbędnej przy produkcji żelaza w kuźnicach. W Przeryciu od 1701 r. istniała kuźnica, należąca do opactwa cystersów w Rudach, z którą związany był staw oraz kanał wodny z przegrodami regulującymi przepływ wody. W 1713 r. powódź zniszczyła tamtejsze stawy (Sufryd, Winiewski 1987). Z treści mapy topograficznej Preußisches Urmesstischblatt wynika, że w 1827 r. kanał był jeszcze częściowo wypełniony wodą. W okresie 1736-1920 wzdłuż Wierzbnika były zlokalizowane 4 młyny wodne i 2 stawy.

\section{Przeobrażenia antropogenicznych odcinków doliny Suminy}

\section{Sumina}

W miejscowości Sumina znajdują się pozostałości dużego stawu, przy którym funkcjonował młyn zbożowy i tartak. Poniżej stawu koryto rzeki zostało przełożone do sztucznego kanału. W miejscu dawnego koryta biegnie dziś nasyp kolejowy. Nowe koryto odcięło cokół wydzielony z IV terasy rzecznej (ryc. 2). Jednocześnie na stoku cokołu, od strony osi doliny, zachował się kanał młynówki. Prawy przyczółek grobli czołowej stawu był sukcesywnie niszczony przez powodzie, a skłon terasy podcinany przez wymuszony meander rzeki. Obserwacje w terenie wskazują, że groblę konsekwentnie odtwarzano i dobudowywano. Naprawy te okazały się jednak nieskuteczne. Zakole rzeki przesuwało się stopniowo ku wschodowi. Po likwidacji tartaku i stawu (między 1919 a 1931 r.) zakole odcięto. Obecnie rzeka płynie przez przekop w dawnej grobli.

Sztuczne koryto Suminy podlegało i nadal podlega silnym procesom erozyjnym i akumulacyjnym. Odcinek ten ma obecnie quasi-naturalny charakter z dwoma poziomami erozyjnymi - około 3-metrowym i 1-1,5-metrowym, z rozwijającymi się meandrami o promieniu 18-20 m i łachami meandrowymi oraz podcięciami wysokiego nawet na 4,5 m brzegu. W dnie opisywanego fragmentu doliny występują liczne powały drzew modyfikujące procesy korytowe. Pnie i konary tworzące zatory biogeniczne, lokalnie podpiętrzają wodę lub stanowią naturalne ostrogi, które przesuwają nurt rzeki. 


\section{Górki Śląskie}

Między Górkami Śląskimi i Bogunicami, w obrębie terasy III, został zbudowany kanał, który stał się korytem zastępczym Suminy (ryc. 3A). Rozpoczyna się on poniżej misy dawnego stawu. Wlot do kanału, a zarazem początkowy odcinek przełomu, został przebudowany. W jego przekroju poprzecznym są widoczne zarysy dwóch usytuowanych piętrowo rynien o trapezoidalnym przekroju. Rynna położona wyżej ma 30-45 m szerokości i do 1,5 m głębokości. Rynna położona niżej sięga swym dnem poziomu terasy zalewowej (na tym odcinku $1 \mathrm{~m}$ ponad korytem), jest węższa (10-15 m) i ma około $2 \mathrm{~m}$ głębokości. W niektórych miejscach meandrujące koryto Suminy podcina zbocza obu rynien, tworząc wysokie brzegi. Najlepiej wykształcone formy rzeźby fluwialnej, z meandrami o promieniach od 15-17 m do 20-22 m i półkami teras, występują na środkowym, zalesionym odcinku kanału.

\section{Mała Nędza}

Kanał przerzutowy wód Suminy w okolicach Małej Nędzy został na odcinku o długości niemal 2,7 km poprowadzony po terasie nadzalewowej (IV) (ryc. 3B). Jego głębokość wynosi tam 4-5 m, maksymalnie dochodzi do 6 m. Na odcinkach, gdzie kanał rozcina terasę holoceńską II i małe fragmenty terasy III, głębokość wcięcia osiąga 3-3,5 m (fot. 1A). Podobnie jak w Suminie, także w tym przypadku niemal cały odcinek strefy przełomowej przypomina doliny rzeczne młodoglacjalnego krajobrazu na Pomorzu. W korycie występują strefy z powalonymi drzewami, które modyfikują przepływ wody i procesy geomorfologiczne. W efekcie wzbogaca to układ siedlisk. Dno i zbocza pierwotnego przekopu podlegały silnej erozji. W obrębie szerokiego na 25-50 m wcięcia można wyróżnić tam trzy poziomy terasowe. Dwa niższe poziomy, około 3-metrowy i 1-1,5-metrowy, mają charakter naturalny (fot. 1B). Najwyższy poziom, występujący zaledwie w kilku miejscach, ma genezę antropogeniczną. Wzdłuż przekopu, na krótkich odcinkach, biegną wały zbudowane z nadmiaru materiału odłożonego przez budowniczych.

Na zachód od drogi z Rud do Raciborza występują obniżenia, którymi epizodycznie przepływała woda ze sztucznego koryta w kierunku osi doliny. Są to prawdopodobnie strefy starych rozmyć powodziowych. W niektórych miejscach pokrywają się one z wciosami dróg kołowych, którymi wywożono masy ziemne z budowanego kanału na groble sypane w dnie doliny Suminy.

W celu zmniejszenia erozji dennej, w korycie poniżej mostu kolejki wąskotorowej, zbudowano próg korekcyjny w postaci podwójnej ścianki z drewnianych pali. Ślady podobnej konstrukcji zachowały się także w korycie potoku Wierzbnik, poniżej grobli stawu w Paszkach. 


\section{Przeobrażenia antropogenicznych odcinków doliny Wierzbnika}

\section{Paszki}

W Paszkach górna część przełomu jest relatywnie szeroka, przez co sprawia wrażenie dość płytkiej. Morfologia dna przypomina tam miejscami opuszczone koryta rzeki roztokowej. W pobliżu południowego przyczółka grobli czołowej stawu widoczne jest rozmycie brzegu kanału ulgi, które zostało zamknięte groblą korekcyjną, kierującą wody powodziowe na terasę IV (ryc. 4A). W dolnym odcinku przełomu wody Wierzbnika stopniowo koncentrowały się, z kilku ramion usytuowanych we wspomnianym szerokim obniżeniu, utworzyły koryto meandrowe i wyrzeźbiły jedno wąskie i głębokie rozcięcie. W tym przypadku, podobnie jak i dwóch następnych przełomów, nie doszło do rozwoju tak urozmaiconej rzeźby fluwialnej, jak w dolinie Suminy. Słabo wykształcony jest przede wszystkim system teras. Należy to tłumaczyć epizodycznymi, wysokimi przepływami powodziowymi, mającymi znaczenie morfotwórcze.

\section{Biały Dwór}

W Białym Dworze początkowy i końcowy odcinek przełomu przecina pasmo wydm usytuowanych na krawędzi terasy IV (ryc. 4B). Przekopy i wcięcia erozyjne osiągają tam 4-6 m głębokości i podobnie jak w Górkach Śląskich i Bogunicach są dwuczęściowe. Część górną stanowi szerokie, płaskodenne obniżenie o przekroju trapezoidalnym, a część dolną trójkątny wcios przypominający debrzę (fot. 2A). Między kanałem a dnem doliny znajdują się dwie okazałe nisze źródliskowe (ryc. 4B). Dwie kolejne zostały zasypane. Dają one początek rozległemu rozcięciu terenu (odcinek b) o charakterze inicjalnego przełomu, powstałego w wyniku erozji wstecznej. Profil podłużny tej formy jest niewyrównany, spadek terenu wykazuje duże lokalne zróżnicowanie (18,4-29,4\%o). W jego obrębie, bliżej osi doliny, znajdują się kolejne misowate nisze źródliskowe, świadczące o dawnych wypływach wód. Największe z nich usytuowane są bliżej dna doliny. Prawdopodobnie funkcjonowały one (lub bardzo zwiększały swą wydajność) podczas powodzi, gdy poziom wód gruntowych w sąsiedztwie stawu podnosił się. Spływ wody uruchamiał duże ilości piasku, który był wynoszony ze zbocza w dno doliny. W środkowym odcinku przełomu, wąskim i głębokim na ponad 2,5 m, widoczne są ślady koryta meandrującego na zapleczu wydm. Jego brzegi były obsadzone szpalerem dębów. Do dziś zachowały się pojedyncze z nich. Ten fragment kanału ma wygląd najbardziej zbliżony do naturalnego, opuszczonego koryta rzecznego. 


\section{Przerycie}

Przełom w Przeryciu składa się z trzech części (ryc. 5). Jego górny V-kształtny odcinek (a) jest głęboki maksymalnie na $6 \mathrm{~m}$, rozcina terasę IV oraz znajdujące się na niej wydmy równolegle do koryta Wierzbnika (fot. 2B). Z naturalnych elementów tej formy należy wymienić V-kształtne rozcięcia dna i kilka kociołkowatych zagłębień w jej osi, będących być może pozostałościami nisz eworsyjnych, usytuowanych poniżej sztucznych lub naturalnych progów (zatorów biogenicznych?). Dolny odcinek (b), wykształcony początkowo jako przelew powodziowy, łączy kanał ulgi (a) z ciekiem. Biegnie on przez zbocze terasy IV oraz misę spiętrzonego w przeszłości, a obecnie osuszonego, stawu na Wierzbniku. Obniżenie (c) jest podobne do inicjalnego przełomu z erozji wstecznej w Białym Dworze. W jego obrębie można wyróżnić cztery nisze źródliskowe. Wody powodziowe z kanału ulgi były pierwotnie wyprowadzane do obniżenia poza pasmo wydm. Stamtąd, omijając kolonię Brantołka, trafiały do dużego stawu w Rudzie Kozielskiej, a następnie do rzeki Rudy. Aby ułatwić odpływ wód w głąb lasu wykonano krótki, płytki przekop (d) między dwiema wydmami. Przed powrotem wód fali powodziowej do doliny Wierzbnika miały chronić groble odgradzające kanał i obniżenie międzywydmowe od wspomnianego stawu na Wierzbniku. Prawdopodobnie w trakcie powodzi groble te były przerywane lub stopniowo podmywane w efekcie erozji rzecznej. Powstał wtedy dolny odcinek przełomu (b) oraz odcinek (c). Grobla zamykająca odcinek (c) została nadbudowana, zaś grobla u wlotu do przelewu (b) - przerwana i pozostaje do dziś rozcięta.

\section{Próba oszacowania objętości mas gruntu wykorzystanego do budowy kanałów i grobli dawnych stawów}

Oszacowano minimalne objętości mas gruntu, które należało przemieścić, aby przekopami popłynęła woda. W obliczeniach przyjęto minimalną, 3-metrową szerokość sztucznego koryta przerzutowego dla wód Suminy i 2-metrową szerokość kanałów ulgi dla wód Wierzbnika oraz nachylenie skarp wykopów 1:1 (45). Wyliczenia te porównano z wynikami pomiarów współczesnej objętości przełomów (tab. 4). W dolinie Suminy objętości przełomów są od 3,2 (Górki Śląskie) do 9,2 (Mała Nędza) razy większe od przyjętej objętości wykopów. Na Wierzbniku objętości przełomów są od 4,7 (Przerycie) do 13,5 (Paszki) razy większe od przyjętej objętości wykopów. Wyniki tych obliczeń nie są jednak wystarczającą podstawą do założenia tak wysokiego udziału procesów naturalnej erozji w rozwoju przełomów. Już samo zwiększenie szerokości koryta i zmniejszenie nachylenia zboczy wykopów wydatnie obniża wartość podanych proporcji. Należy pamiętać o tym, że pozyskane masy ziemne wykorzystywano także do sypania grobli stawów i nasypów drogowych. 

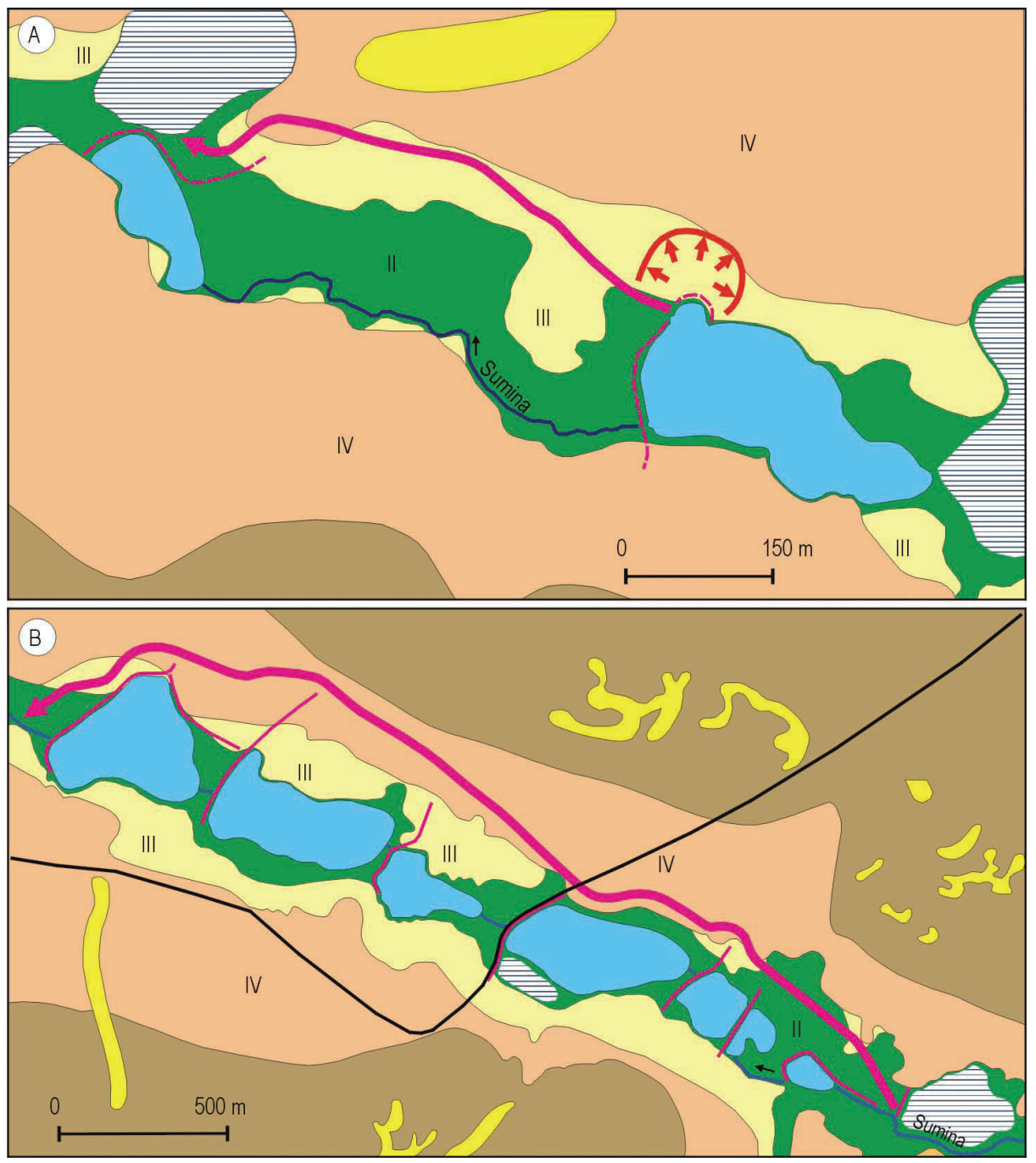

Ryc. 3. Rekonstrukcja zasięgu stawów (dla stanu wód podczas wezbrań powodziowych) i przebiegu kanałów w dolinie Suminy w: (A) Górkach Śląskich i (B) Małej Nędzy

Fig. 3. Reconstruction of pond shoreline (for the water level reached during floods) and the course of canals in the Sumina River valley in: (A) Górki Śląskie and (B) Mała Nędza

Objaśnienia jak do ryc. 2.

Explanations as in Fig. 2. 

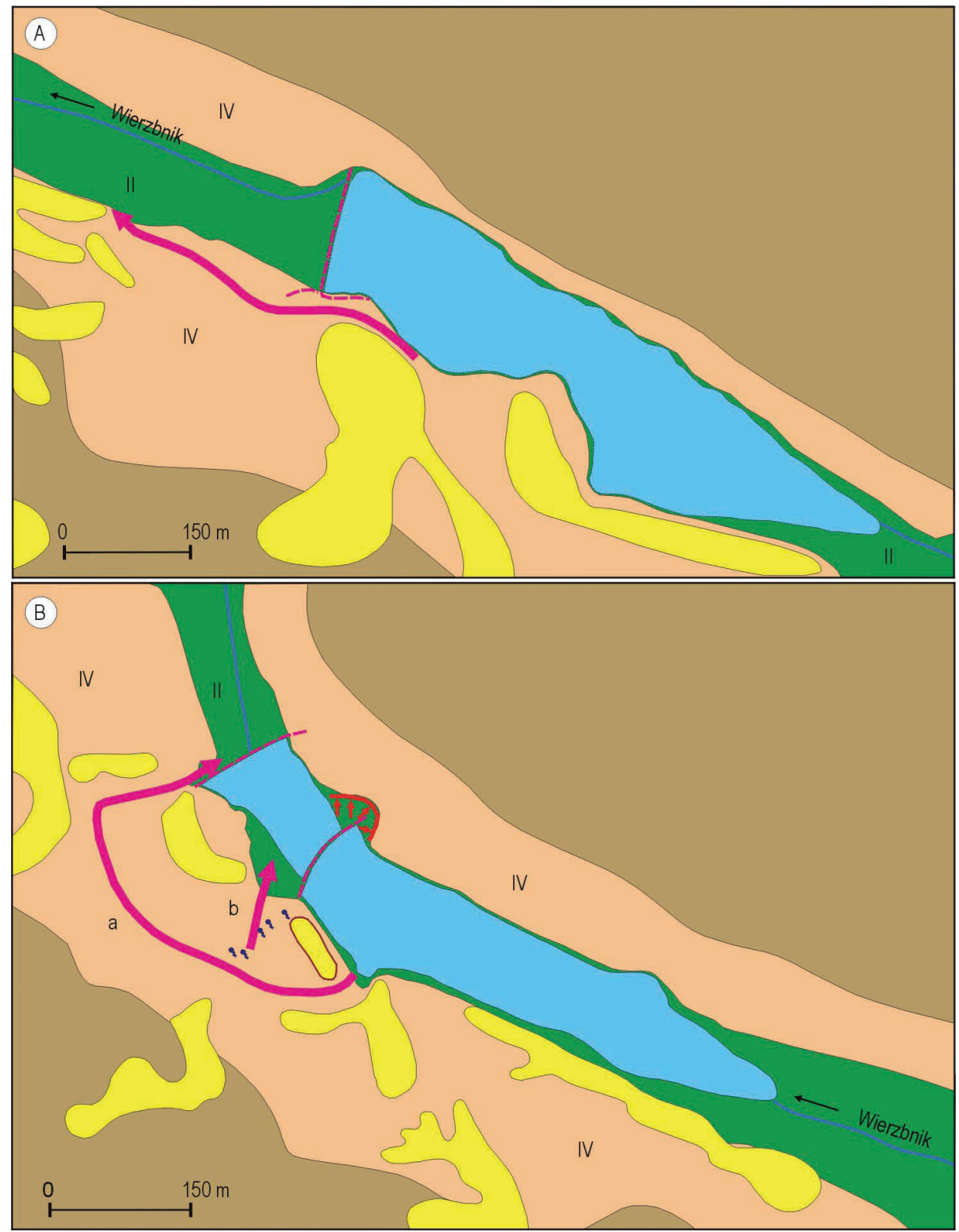

Ryc. 4. Rekonstrukcja zasięgu stawów (dla stanu wód podczas wezbrań powodziowych) i przebiegu kanałów w dolinie Wierzbnika w: (A) Paszkach, (B) Białym Dworze Fig. 4. Reconstruction of pond shoreline (for the water level reached during floods) and the course of canals in the Wierzbnik River valley in: (A) Paszki, (B) Biały Dwór

Objaśnienia jak do ryc. 2. B: a - kanał ulgi, b - inicjalny przełom powstały w wyniku erozji wstecznej. Explanations as in Fig. 2. B: a - bypass, b-initial gorge formed as a result of headward erosion. 

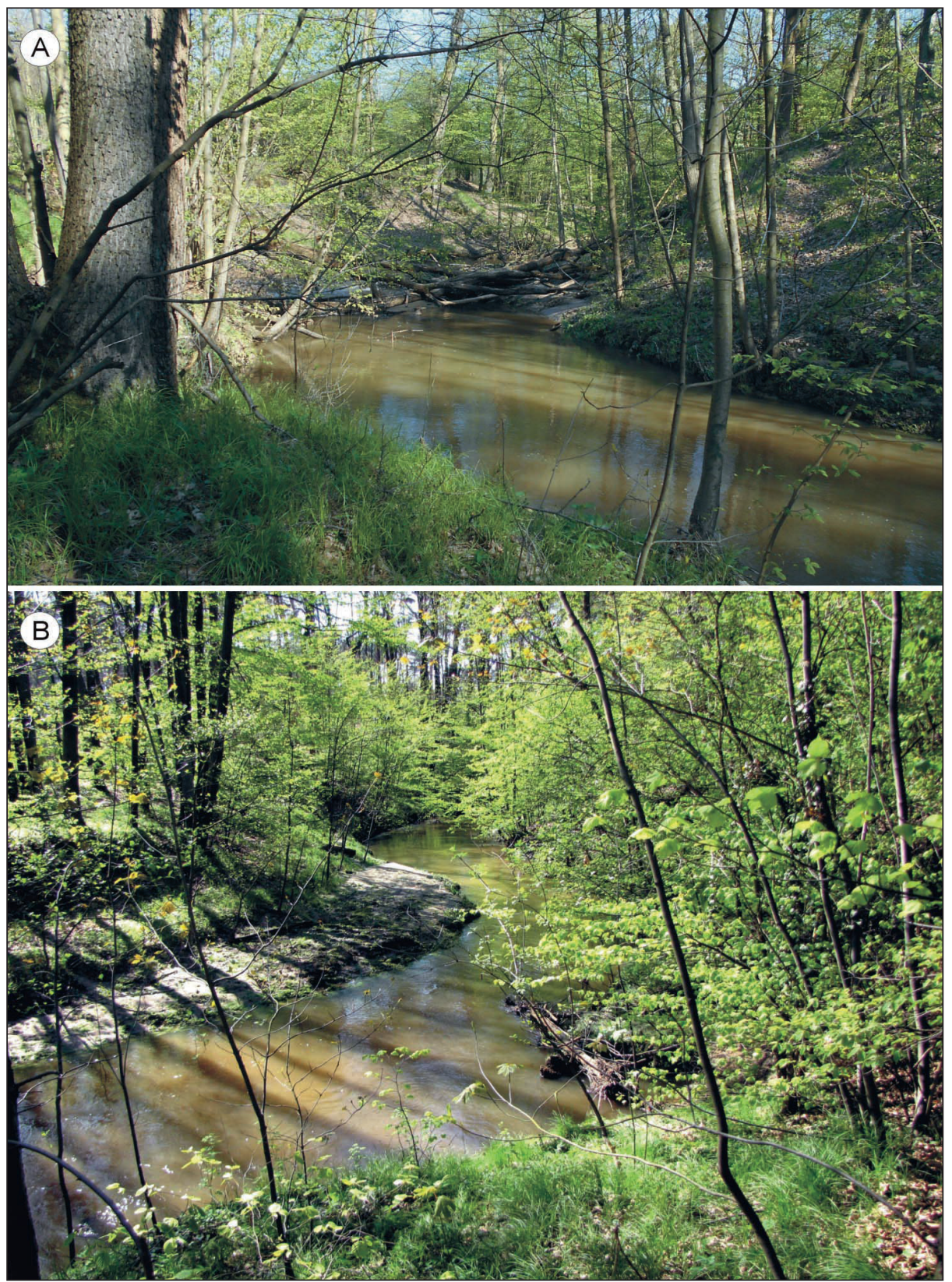

Fot. 1. Antropogenicznie uwarunkowany przełom Suminy w Małej Nędzy: (A) koryto rzeki rozcinające terasę nadzalewową, (B) dwa poziomy terasowe i odsyp meandrowy

Photo 1. Anthropogenically determined gorge of the Sumina River at Mała Nędza: (A) river channel dissecting the meadow terrace, (B) two terrace levels and a meander bar 

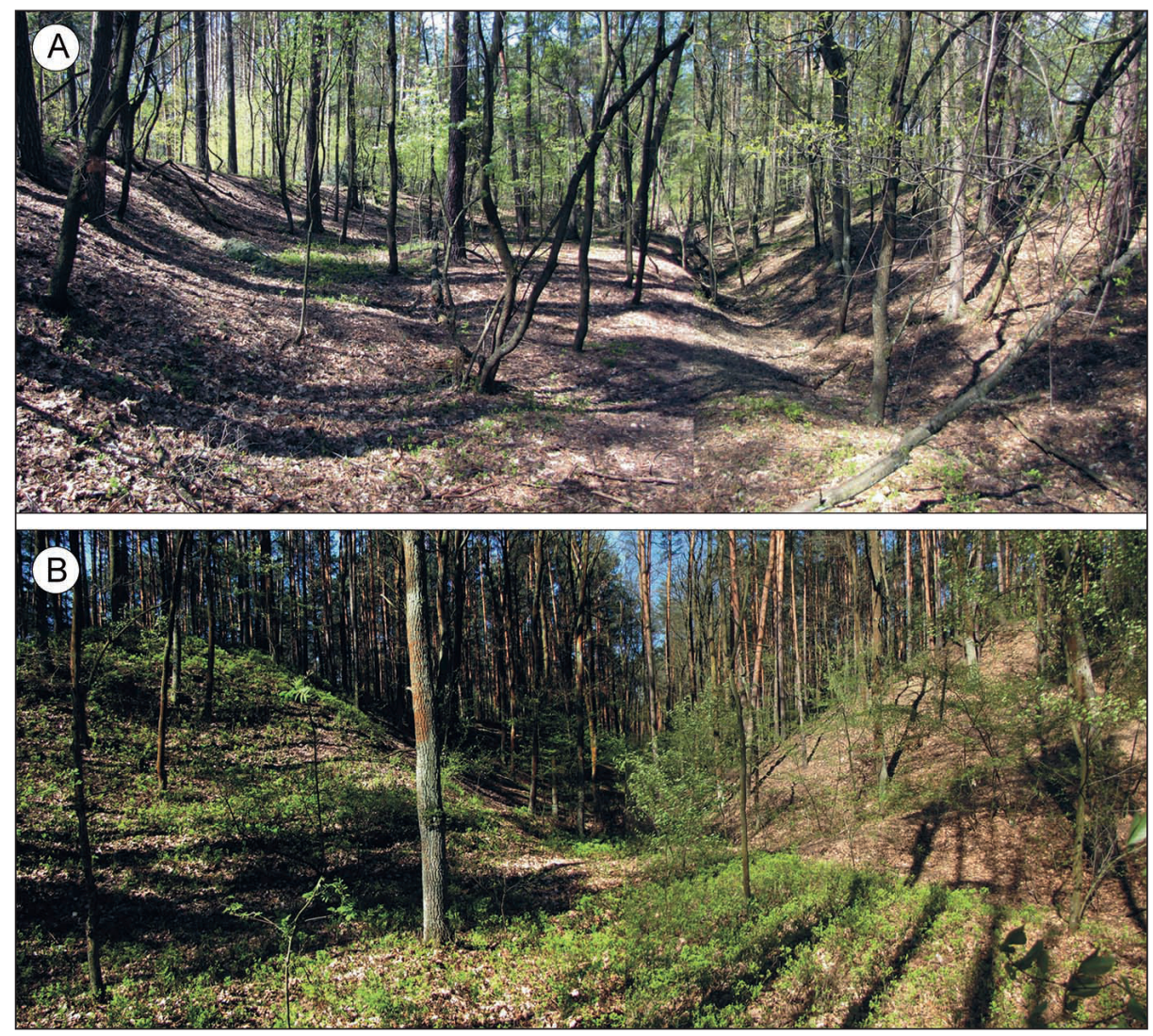

Fot. 2. Antropogenicznie uwarunkowane przełomy rzeczne na dawnych kanałach ulgi Wierzbnika w: (A) Białym Dworze i (B) Przeryciu

Photo 2. Anthropogenically determined river gorges on the old bypasses of the Wierzbnik River at: (A) Biały Dwór and (B) Przerycie 


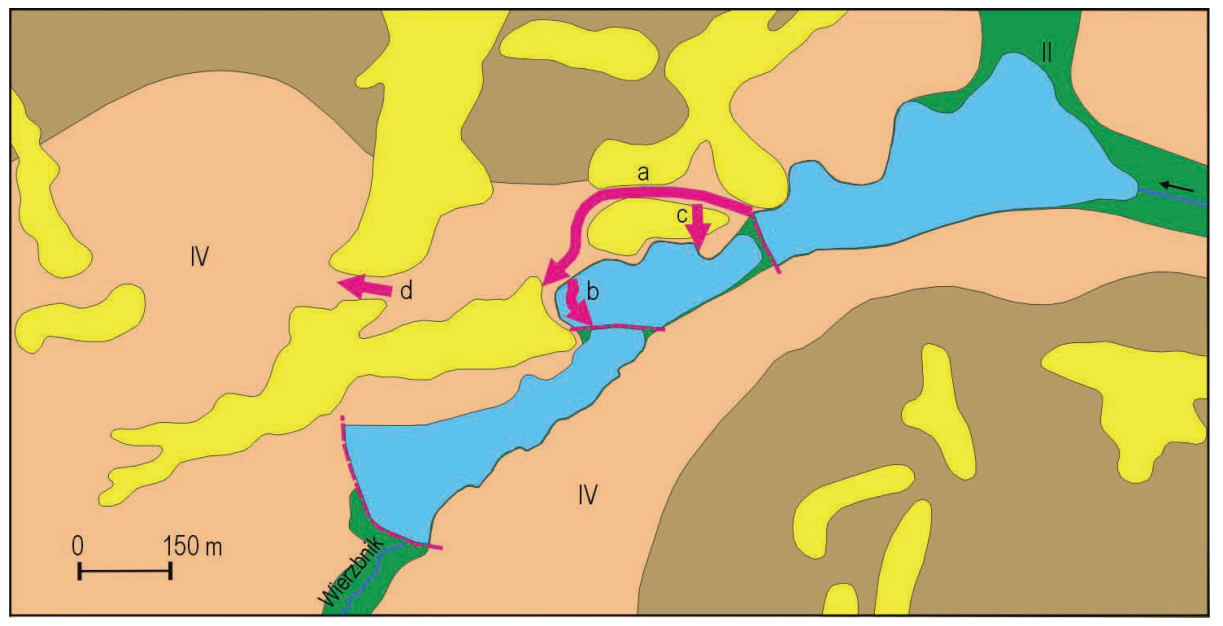

Ryc. 5. Rekonstrukcja zasięgu stawu (dla stanu wód podczas wezbrań powodziowych) i przebiegu kanałów w dolinie Wierzbnika w Przeryciu

Fig. 5. Reconstruction of pond shoreline (for the water level reached during floods) and the course of canals in the Wierzbnik River valley in Przerycie

Objaśnienia jak do ryc. 2.: a - kanał ulgi, b, c-inicjalny przełom powstały w wyniku erozji wstecznej lub przelew powodziowy, d - przekop między wydmami.

Explanations as in Fig. 2.: a - bypass, b, c-initial gorge formed as a result of headward erosion or flood spillway, $\mathrm{d}$ - cutting between the dunes. 
Tab. 4. Porównanie objętości przekopów i grobli stawów w stosunku do objętości przełomów Table 4. Cutting and pond dyke volumes compared to gorge volumes

\begin{tabular}{|c|c|c|c|c|c|c|}
\hline \multirow{2}{*}{$\begin{array}{l}\text { Porównywane objętości } \\
\text { Volumes compared }\end{array}$} & \multicolumn{3}{|c|}{ Sumina } & \multicolumn{3}{|c|}{ Wierzbnik } \\
\hline & Sumina & $\begin{array}{c}\text { Górki } \\
\text { Śląskie }\end{array}$ & $\begin{array}{l}\text { Mała } \\
\text { Nędza }\end{array}$ & Paszki & $\begin{array}{l}\text { Biały } \\
\text { Dwór }\end{array}$ & Przerycie \\
\hline $\begin{array}{l}\text { Procentowy udział objętości przekopu w całkowitej } \\
\text { objętości przełomu } \\
\text { Cutting volume as a percentage of total gorge volume }\end{array}$ & 17,5 & 31,3 & 10,9 & 7,4 & $\begin{array}{l}\text { (a) } 9,3 \\
\text { (b) } 4,1\end{array}$ & $\begin{array}{l}\text { (a) } 21,3 \\
\text { (b) } 66,7\end{array}$ \\
\hline $\begin{array}{l}\text { Wielokrotność objętości przełomów w stosunku } \\
\text { do objętości wykopów } \\
\text { Gorge volume as a multiple of cutting volume }\end{array}$ & 5,7 & 3,2 & 9,2 & 13,5 & $\begin{array}{l}\text { (a) } 10,8 \\
\text { (b) } 24,1\end{array}$ & $\begin{array}{l}\text { (a) } 4,7 \\
\text { (b) } 1,5\end{array}$ \\
\hline $\begin{array}{l}\text { Procentowy udział objętości grobli sąsiednich stawów } \\
\text { w całkowitej objętości przełomu } \\
\text { Percentage share of adjacent pond dyke volume } \\
\text { in total gorge volume }\end{array}$ & $n^{1)}$ & $n^{1)}$ & $n^{1)}$ & 33,5 & (a) 14,4 & (a) 26 \\
\hline
\end{tabular}

1) Dla przełomów w dolinie Suminy nie dokonano obliczeń, ponieważ obiekty hydrotechniczne powstały w różnych latach i były wielokrotnie przebudowywane. Nie można zatem zakładać prostego związku między objętością budowanych kanałów i pobliskich grobli.

(a) kanał ulgi (b) przelew powodziowy (por. ryc. 4).

1) No calculations were conducted for the gorges in the Sumina River valley because the hydro-engineering structures there were constructed in different periods and were altered many times and therefore no simple relationship can be assumed between the volume of constructed canals and nearby dykes.

(a) bypass (b) flood spillway (cf. Fig. 4).

Na podstawie pomiarów pozostałości grobli piętrzących obliczono, że grobla czołowa stawu w Paszkach mogła mieć $5000 \mathrm{~m}^{3}$ objętości, grobla górnego stawu w Białym Dworze $2500 \mathrm{~m}^{3}$, stawu dolnego $1200 \mathrm{~m}^{3}$, a grobla stawu w Przeryciu nawet $7000 \mathrm{~m}^{3}$. W tabeli 4. podano procentowy udział objętości mas ziemnych wykorzystanych w dolinie Wierzbnika na budowę grobli pobliskich stawów w stosunku do objętości przełomów. W rozważaniach tych trzeba również uwzględnić ilość materiału pobieranego z dna doliny, głównie z mis tworzonych stawów i z kanałów młynówek. Szczególnie przydatne były: muł, ił i glina, z których tworzono ekrany izolacyjne, chroniące groble przed przesiąkaniem. W razie niedostatku materiału przywożono go z dalszej odległości. 


\section{Dyskusja}

Sposobem ochrony stawów i obiektów hydrotechnicznych na Suminie i Wierzbniku przed ekstremalnie wysokim przyborem wód była budowa kanałów ulgi, odprowadzających wody powodziowe poza stawy i młyny. Podobne rozwiązania stosowano w dolinie Rudy. Ślady ulg powodziowych spotyka się m.in. w Górnej Hucie, gdzie wykorzystano płytkie obniżenie, prawdopodobnie w strefie paleomeandrów, oraz długi na 1,6 km kanał między Przeryciem i Brantołką (Waga 2003).

Sztuczne przekopy związane z funkcjonowaniem dawnych zakładów wykorzystujących energię wodną występują w dolinach wielu rzek, nie tylko na Wyżynie Śląskiej. Najczęściej są to kanały młynówek prowadzone po równinie zalewowej. Zwykle wykonywano przekop, skracając zakole rzeki. Uzyskiwano w ten sposób zwiększony spadek, a przez to większą energię płynącej wody. Niekiedy wykorzystywano rozwidlenie koryta rzeki i jedno z ramion zamieniano w kanał młynówki (m.in.: Brykała 2001; Podgórski 2004; Parzóch, Solarska 2008; Witek 2012). Rzadziej natomiast kopano kanały młynówek na wysoczyznach czy na terasach nadzalewowych (Parzóch, Solarska 2008; Fajer 2011).

Budowa kanału Suminy, o prostym przebiegu i większym spadku niż miało naturalne koryto rzeki, stworzyła warunki do uruchomienia intensywnych procesów erozji, które prowadziły do pogłębiania i poszerzania sztucznego koryta. Większy spadek kanału wynikał z dwóch przyczyn. Pierwszą było skrócenie biegu rzeki, drugą podwyższenie punktu początkowego krzywej erozyjnej z poziomu dna doliny do wysokości przelewu burzowego, usytuowanego tuż poniżej rzędnej korony grobli czołowej. Dla przykładu, szacowane wysokości grobli czołowych wynoszą: w Paszkach - 2,5 m, w Białym Dworze (staw górny) - 3 m, w Przeryciu - 4,2 m.

Opisywane formy terenu mają dwojaką genezę. Najpierw powstał sztuczny kanał, do którego przerzucono koryto rzeki. Odtąd dno kanału było kształtowane przez procesy erozji, szczególnie intensywnie przy udziale wód powodziowych. Prawdopodobnie wówczas powstawały niższe rynny w Górkach Śląskich i Białym Dworze. Ostatecznie na większości odcinków dawnych kanałów naturalne procesy erozji dennej i bocznej przeobraziły to, co utworzył człowiek. W przypadku przełomów w Suminie i Małej Nędzy kanały uległy tak dużym przekształceniom, że dziś są najbardziej naturalnie wyglądającymi fragmentami doliny rzecznej. Podobne tendencje są obserwowane w innych dolinach rzecznych, m. in. Oławy i Krynki, gdzie dawne, wielokilometrowe kanały wycięte w obrębie wysoczyzn ulegają procesom naturalizacji. Zwiększenie krętości ich koryt jest wymuszane, podobnie jak w przypadku Suminy, przez drzewa porastające brzegi oraz nieużytkowane obiekty hydrotechniczne (Parzóch, Solarska 2008). W Europie Środkowej jest wiele małych cieków, które pierwotnie były sztucznymi kanałami, a później uległy naturalizacji (Müller i in. 2004). 
Zygmunt (2003), na podstawie badań dendrochronologicznych prowadzonych w przełomowym odcinku Suminy pomiędzy Górkami Śląskimi i Nędzą, określiła wiek wymodelowania poziomów terasowych na 160 lat (wyższy) i 55 lat (niższy). Na podstawie analizy archiwalnych map Autorka uznała, że przełomowy odcinek Suminy kształtowany jest od co najmniej 270 lat. Według Klimka i in. (2001) powstanie tego przełomu zostało zapoczątkowane utworzeniem dużego stawu z groblą, w miejscu której dziś biegnie droga Racibórz - Rudy. Prawdopodobnie początek formowania tych przełomów sięga jednak znacznie dalej w przeszłość. Zapis o stawach rybnych w Suminie pochodzi z początku XIV w. (Sufryd, Winiewski 1987), a wiek XVI był okresem budowy systemów dużych stawów w dolinach rzecznych na Śląsku (Nyrek 1997).

Według Zygmunt (2003) tempo erozji dennej w strefie przełomu było zróżnicowane, od 4,1 cm $\cdot \mathrm{rok}^{-1} \mathrm{w}$ latach 1736-1846, 1,4 $\mathrm{cm} \cdot \mathrm{rok}^{-1} \mathrm{w}$ latach 1846-1949 do $2,8 \mathrm{~cm} \cdot \mathrm{rok}^{-1} \mathrm{w}$ latach $1949-2002$. Na analizowanym odcinku Suminy nadal zachodzą intensywne procesy erozji dennej, będące przejawem dążenia rzeki do poziomu bazy erozyjnej. Zwiększa się również krętość koryta, a zatem też jego długość. Simon (1989) i Simon, Rinaldi (2006) opracowali model ewolucji skanalizowanego i pogłębionego koryta rzeki, wskazując kierunek jego przeobrażeń. Autorzy wyróżnili sześć etapów rozwoju koryta: przedmodyfikacyjny, przebudowy, degradacji, progowy, agradacji i stabilizacji. Dla każdego etapu zostały wskazane dominujące procesy fluwialne i stokowe w połączeniu z charakterystycznymi formami korytowymi. Zgodnie z tym modelem piaskodenne koryta osiągają etap stabilizacji i początki rozwoju meandrów w ciągu 50-100 lat (Simon 1989). Transformacja koryta Suminy w przełomach, w porównaniu z tym modelem, odpowiada na niektórych odcinkach etapowi degradacji, przejawiającej się nasileniem erozji dennej i bocznej, a na innych - etapowi erozji bocznej i agradacji. Rzeka formuje koryto z odsypami meandrowymi, które lokalnie w czasie wezbrań są nadbudowywane piaszczystym osadem.

We wszystkich badanych przypadkach, zarówno głębokie wcięcia erozyjne w obrębie antropogenicznych kanałów wodnych, jak i szerokie rozmycia brzegów są związane z ekstremalnie wysokimi przepływami. Ostatecznie to one spowodowały destrukcję systemów hydrotechnicznych w dolinie Wierzbnika. Należy sądzić, że w rozmywaniu wałów bocznych wzdłuż kanałów ulgi w dolinie Wierzbnika istotną rolę, poza gwałtownymi wezbraniami, mogła odegrać łatwa infiltracja wód w podłoże składające się przede wszystkim z piasków ze żwirami.

Koszty naprawy szkód powodziowych stawały się zbyt wysokie, zapewne także w kontekście stopniowego wprowadzania nowych źródeł energii oraz przeobrażeń organizacyjnych, technologicznych i ekonomicznych w gospodarce stawowej. W zakładach przemysłowych i warsztatach, które korzystały z energii wód płynących, zaczęto stosować silniki parowe, spalinowe, a następnie elektryczne. W II połowie XIX w. na Górnym Śląsku kończył się czas wielofunkcyjnych stawów, budowanych na „kapryśnych” rzekach i potokach. 
Określenie przełom Suminy został użyty przez Zygmunt (2002, 2003) dla odcinka poniżej Górek Śląskich. Autorka wiązała genezę tej formy z budową dużego stawu, skróceniem koryta i nasileniem procesu erozji dennej. Już wtedy pojawił się problem zdefiniowania silnie wciętego odcinka koryta Suminy jako przełomu w kontekście działań człowieka (Zygmunt 2003). We wszystkich sześciu przykładach opisanych w niniejszym artykule stwierdzono duży udział człowieka w kierowaniu spiętrzonych wód rzecznych, także powodziowych, do sztucznych koryt. Jednakże występująca później erozja denna działała podobnie, jak w przypadku rozwoju przełomów przelewowych.

\section{Wnioski}

Małe rzeki odgrywały istotną rolę w gospodarce od czasów średniowiecznych. Budowa, funkcjonowanie i likwidacja młynów wodnych oraz stawów (młyńskich i rybnych) były czynnikami wpływającymi na zmiany biegu koryt i na przebieg procesów fluwialnych.

Zapisane w rzeźbie dolin Suminy i Wierzbnika głębokie rozcięcia erozyjne są naturalnie przekształconymi formami antropogenicznymi - dawnymi kanałami zastępczymi lub kanałami ulgi, które w przeszłości były częścią sztucznych systemów wodnych w zlewniach tych rzek. Kanały powodziowe, do których odprowadzano nadmiar wody, były zabezpieczeniem dla młynów wodnych i stawów hodowlanych.

Odcinki dawnych kanałów Suminy przekształcane przez procesy fluwialne uległy naturalizacji. Jest tam obserwowany wzrost krętości koryta i rozwój meandrów. Koryto rzeki jest dłuższe, średnio o 9,3\%, od dawnego kanału. Największą różnicę zanotowano na odcinku w Suminie (o 26,2\%). Paradoksalnie, w ich obrębie można aktualnie obserwować naturalne procesy rozwoju doliny rzecznej, dlatego dwa z opisanych obiektów, tj. w Suminie i w Małej Nędzy (odcinek na zachód od drogi Rudy - Racibórz) zasługują na ochronę prawną. W dolinie Wierzbnika dawne kanały zostały osuszone i przemodelowane przez procesy geomorfologiczne. Nadal są jednak czytelne w rzeźbie terenu.

Dawne kanały Suminy i Wierzbnika swoimi cechami przypominają przełomy rzeczne. Dla takich form proponuje się wprowadzenie terminu antropogenicznie uwarunkowane przełomy rzeczne.

\section{Literatura}

Absalon D., 1998, Antropogeniczne zmiany odpływu ræecznego w zlewni Rudy, Prace Naukowe Uniwersytetu Śląskiego w Katowicach, 1732, Katowice.

Absalon D., Jankowski A.T., Leśniok M., 2003, Komentarz do Mapy hydrograficznej w skali 1:50000, Ark. M-34-61-D Wodzistaw Ślaski, Urząd Marszałkowski Województwa Śląskiego, Katowice. 
Brykała D., 2001, Uwarunkowania przyrodnicze lokalizacji młynów wodnych w zlewni Skrwy, Problemy Ekologii Krajobrazu, 10, 164-171.

Fajer M., 2011, Antropogenicæne przeobrażenia den dolin ræecznych na Wyżynie Woźnicko-Wieluńskiej w XVIII-XX w., [w:] A. Zieliński (red.), Znane fakty - nowe interpretacje w geologii i geomorfologii, Instytut Geografii, Uniwersytet Jana Kochanowskiego, Kielce, 9-22.

Foltyn E.M., Foltyn E., 2012, Ziemie Górnego Ślaska od epoki kamienia do wcæesnego średniowiecza, Muzeum Śląskie w Katowicach.

Hibszer A., 1988, Bilans wodny zlewni Suminy po wodowskaz wędzy, Wydział Nauk o Ziemi Uniwersytet Śląski, Sosnowiec, praca magisterska, maszynopis.

Karaś-Brzozowska C., 1963, Zasięg zlodowacenia środkowopolskiego w Kotlinie Raciborskiej, Przegląd Geograficzny, 35 (3), 431-447.

Klimek K., 1972, Kotlina Raciborsko-Oświęcimska, [w:] M. Klimaszewski (red.), Geomorfologia Polski, t. 1, PWN, Warszawa, 116-138.

Klimek K., Kocel K., Śnieszko Z., Wójcicki K., Zygmunt E., 2001, Pokrywy stokowe w Kotlinie Górnej Odry, [w:] K. Klimek, K. Kocel (red.), Pokrywy stokowe jako zapis zmian klimatycznych w póঞnym vistulianie i holocenie, Wyd. Wydział Nauk o Ziemi Uniwersytet Śląski, Sosnowiec, $1-27$.

Kocel K., 1995, Stawy w dolinie Rudy (Górny Ślask) jako wskaźnik antropogenicznych zmian krajobrazu, [w:] A.T. Jankowski, T. Szczypek (red.), Præeobrażenia środowiska geograficznego w przygranicznej strefie górnoślasko-ostrawskiego regionu przemystowego, Materiały Sympozjum Polsko-Czeskiego, Wydział Nauk o Ziemi Uniwersytet Śląski, Park Krajobrazowy Cysterskie Kompozycje Krajobrazowe Rud Wielkich, Sosnowiec, 57-62.

Kotlicka G.N., Kotlicki S., 1979, Mapa geologicæna Polski 1:200 000, Ark. Gliwice, Państwowy Instytut Geologiczny, Warszawa.

Kotlicka G.N., Kotlicki S., 1980, Objaśnienia do mapy geologicznej Polski 1:200 000, Ark. Gliwice, Państwowy Instytut Geologiczny, Warszawa.

Lewandowski J., 2003, Plejstocen glacjalny Kotliny Raciborsko-Ośrięcimskiej i obszarów sqsiednich, [w:] J. Haisig, J. Lewandowski (red.), Plejstocen Kotliny Raciborsko-Oswięcimskiej na tle struktur morfotektonicznych podto: a czwartoræędu, X Konferencja Stratygrafia plejstocenu Polski, Państwowy Instytut Geologiczny, Uniwersytet Śląski, Sosnowiec, 16-29.

Migoń P., 2006, Geomorfologia, PWN, Warszawa.

Müller G., Himmelsbach G., Carmer C., Fröhle P., 2004, Small river re-naturalization and cultural heritage, [w:] M. Greco, A. Carravetta, R. Della Morte (red.), River Flow, 2, 763-778.

Nyrek A., 1995, Ekologične uwarunkowania rowwoju Polski-præesztość i terazniejszość, Słupskie Studia Historyczne, 4, 3-20.

Nyrek A., 1997, Gospodarczo-spoteczne przyczyny i skutki ekologic*ne powodzi na Ślasku od XV w. do XX w. w dotychczasowych badaniach, Słupskie Studia Historyczne, 5, 75-89.

Paleczek W., 2015, Analiza dokładności obliczania objętości mas ziemnych, Zeszyty Naukowe Politechniki Częstochowskiej 171, Budownictwo, 21, 365-371.

Parzóch K., Solarska A., 2008, Antropogenicæna præebudowa den dolinnych Præedgóræa Sudeckiego na przykładzie Otawy i Krynki, Landform Analysis, 9, 314-318. 
Plit J., 2006, Analiza historyczna jako \&ródto informacji o środowisku przyrodniczym, Problemy Ekologii Krajobrazu, 16, 217-226.

Pociask-Karteczka J. (red.), 2006, Zlewnia. Wtaściwości i procesy, Wydawnictwo Uniwersytetu Jagiellońskiego, Kraków.

Podgórski Z., 2004, Wpływ budowy i funkcjonowania młynów wodnych na ræeźbę terenu $i$ wody powierzchniowe Pojezierza Chetmińskiego i przylegtych części dolin Wisty i Drwęcy, Uniwersytet Mikołaja Kopernika, Toruń.

Rybant S., 1977, Średniowieczne opactwo cystersów w Rudach, Prace Wrocławskiego Towarzystwa Naukowego, ser. A, 195, 5-181.

Simon A., 1989, A model of channel response in disturbed alluvial channels, Earth Surface Processes and Landforms, 14, 11-26.

Simon A., Rinaldi M., 2006, Disturbance, stream incision, and channel evolution: The roles of excess transport capacity and boundary materials in controlling channel response, Geomorphology, 79, 361-383.

Strumieński O., 1573, O spráwie, sypániu, wymiérzániu i rybieniu stáwów, tákże o præekopách, o ważeniu i prowádzeniu wody. Ksiqżki wszystkim gospodarzóm potrzebné, [transkrypcja i reprodukcja fototypiczna], Instytut Śląski w Opolu, 1987.

Sufryd M., Winiewski J., 1987, Opactwo cystersów w Rudach 1258-1810, Katowice.

Waga J.M., 1994, Rzeźba eoliczna na obszarze weschodniej czessci Niecki Kozielskiej, Scripta Rudensia, 2, 1-129.

Waga J.M., 2003, Lokalizacja stawów i sposoby ich zabezpiecæania præed skutkami powodæi w dolnej części zlewni Rudy na Górnym Ślasku, [w:] J.M. Waga, K. Kocel (red.), Catowiek w środowisku przyrodniczym - zapis działalności, P'TG Oddział Katowicki, Sosnowiec, 220-224.

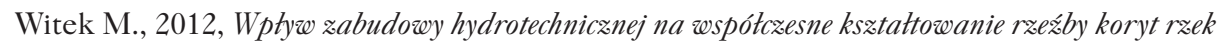
ziemi kłodzkiej, Landform Analysis, 19, 91-102.

Zygmunt E., 2002, Transformacja koryta rzeki Suminy pod wptywem antropopresji (Kotlina Raciborska, Dorzecze Górnej Odry), [w:] P. Szwarczewski, E. Smolska (red.), Zapis dziatalności człowieka w środowisku przyrodniczym, Warszawa, 151-154.

Zygmunt E., 2003, Zmiana biegu rzeki Suminy pod wptywem antropopresji (Kotlina Raciborska), [w:] J. M. Waga, K. Kocel (red.), Citowiek w środowisku przyrodniczym - zapis dziatalności, PTG Oddział Katowicki, Sosnowiec, 244-248.

\author{
Maria Fajer \\ Uniwersytet Ślqski \\ Wydziat Nauk o Ziemi \\ ul. Będzińska 60, 41-200 Sosnowiec \\ maria.fajer@us.edu.pl
}

